\title{
The Effectiveness of The use of Snake and Ladder Media in The Material of The Kingdoms of Islam, Hinduism and Buddhism Based on The Hots Problem of Students Learning Outcomes in Elementary Schools
}

\section{Efektivitas Penggunaan Media Ular Tangga Pada Materi Kerajaan Islam, Hindu dan Budha Berbasis Soal Hots Terdahap Hasil Belajar Siswa di SDN Ngaringan 03 Blitar}

\author{
Nuril Nuzulia ${ }^{1 *}$ \\ Universitas Islam Negeri Maulana Malik Ibrahim Malang, Indonesia
}

OPEN ACCESS

ISSN 2579-5813 (online)

Edited by:

Nurdyansyah

Reviewed by:

Marzuki Ibrahim

${ }^{*}$ Correspondence:

Nuril Nuzulia

nurilnuzulia@gmail.com

Received:3 Februari 2021

Accepted: 10 Maret 2021

Published: 30 April 2021

Citation:

Nuzulia N, (2021) The Effectiveness of the use of Snake and Ladder Media in The Material of The Kingdoms of Islam, Hinduism and Buddhism Based on The Hots Problem of Students Learning Outcomes in Elementary

Schools.

Madrosatuna: Journal of Islamic Elementary School. 5:1.

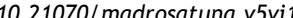

This research is motivated by the availability of the snake and ladder game on the material of the kingdoms of Islam, Hinduism and Buddhism based on HOTS questions which have not been tested for their effectiveness on student learning outcomes. This study aims to reveal the effectiveness level of the use of snake and ladder media in the material of Islamic, Hindu and Buddhist kingdoms on student learning outcomes at SDN Ngaringan 03 Blitar. This type of research is a quasi-experimental research design with a non-equivalent control group design. The population in this study were grade 4 students at SDN Ngaringan Blitar. The research sample was taken using purposive sampling technique so that class $4 \mathrm{~A}$ was selected as the experimental class and class $4 \mathrm{~B}$ as the control class. The instrument of this research is a test of learning outcomes by providing a pretest and posttest in the form of an objective test with 4 answer choices as many as 25 items taken from 40 questions that have been tested. The data analysis technique used was the N-Gain test and the two-mean similarity test (t-test). The results showed an increase in learning outcomes was better in the experimental class than in the control class. This is evidenced by the posttest mean scores of the experimental class and the control class respectively 92.12 and 73.96 . This is also evidenced by the average N-Gain test for the experimental class of 0.762 with the high category and the control class of 0.294 in the low category, and supported by hypothesis testing carried out by t-test using the Independent Samples Test showing Sign 2 Tailed $<0.05$, this indicates that the use of snake and ladder media is effective. 
Penelitian ini dilatar belakangi oleh tersedianya permainan ular tangga pada materi kerajaan Islam, Hindu, dan Budha berbasis soal HOTS yang belum diuji efektivitasnya terhadap hasil belajar siswa. Penelitian ini bertujuan untuk mengungkapkan tingkat efektivitas penggunaan media ular tangga pada materi kerajaan Islam, Hindu, dan Budha terhadap hasil belajar siswa di SDN Ngaringan 03 Blitar. Jenis penelitian yang digunakan adalah eksperimen semu dengan rancangan penelitian non-equivalent control group design. Populasi pada penelitian ini adalah siswa kelas 4 di SDN Ngaringan Blitar. Sampel penelitian diambil dengan menggunakan teknik purposive sampling sehingga terpilih kelas $4 \mathrm{~A}$ sebagai kelas eksperimen dan kelas 4 B sebagai kelas kontrol. Instrument penelitian ini adalah tes hasil belajar dengan memberikan pretest dan posttest berupa tes objektif dengan 4 pilihan jawaban sebanyak 25 butir soal yang diambil dari 40 soal yang telah diujicobakan. Teknik analisis data yang digunakan adalah uji N-Gain dan uji kesamaan dua rata-rata (uji-t). Hasil penelitian menunjukkan peningkatan hasil belajar yang lebih baik terjadi di kelas eksperimen dibandingkan kelas kontrol. Hal ini dibuktikan dengan rata-rata nilai posttest kelas eksperimen dan kelas kontrol masing-masing sebesar 92,12 dan 73,96. Hal ini juga dibuktikan dengan rata-rata uji $\mathrm{N}$-Gain kelas eksperimen sebesar 0,762 dengan kategori tinggi dan kelas kontrol sebesar 0,294 dengan kategori rendah, serta didukung oleh uji hipotesis yang dilakukan dengan uji-t dengan menggunakan Independent Samples Test dengan menunjukkan Sign 2 Tailed $<0,05$, Hal ini menandakan bahwasannya penggunaan media ular tangga efektif.

Kata Kunci: Efektivitas, Media Ular Tangga, Hasil Belajar 


\section{PENDAHULUAN}

Dunia pada hari ini semakin merasakan sebuah kemajuan dengan begitu pesat. kemajuan didalam dunia yang selanjutnya memiliki pengaruh terhadap beberapa bidang mengikuti ikut pula mengalami perubahan dan mengalami sebuah perkembangan sama seperti zaman saat ini. Dunia Pendidikan juga turut serta mengalami suatu perkembangan. Tujuan perkambangan dunia pendidikan agar mengikuti dan tidak tertinggal oleh perkembangan zaman, sehingga pendidikan ikut mengalami peruberubahan, tidak terkecualikan di negara Indonesia.

Pendidikan adalah suatu yang mutlak diperlukan oleh seorang manusia. dalam kelangsungan hidupnya seorang manusia tidak harus tercukupkan dengan tumbuh kembang melalui dorongan dari suatu insting, akan tetapi memerlukan suatu tuntunan dari luar diri. Selain itu juga mempunyai peran meningkatkan kualitas mewujudkan pembelajaran yang alangkah baik dan siswa dapat aktif mengembangkan potensiya. Sebuah Bimbingan dari luar inilah yang bisa disebut sebagai sebuah pendidikan. Pendidikan merupakan sebuah perubahan yang dialami oleh seseorang agar mampu mengeksplor suatu potensi dan sebuah bakat diri, menaiakan kecerdasan, keterampilan, mengangkat budi pekerti, memperkokoh kepribadian, menaikan nilai spiritual agama dan memperkuan sebah rasa semangat kesatuan untuk mampu menciptakan diri individu bersama-sama memperbaiaki negaradan bangsa. Patoni et al. (2004)

Berdasarkan Undang-undang RI Nomor. 20 tahun 2003 yang berisikan sebuah aturan didalam Pendidikan Nasional bab I pasal 1 mengungkapkan suatu pendidikan merupakan suatu proses yang paham dan memiliki rencana tercapainya suatu pembelajaran dan sebuah jalan kegiatan pembelajaran supaya siswa menjadi semangat dalam mengembangkan kemampuan dalam diri agar dapat mempunyai kedalaman spiritual keagamaaan, akhlak mulia, pengendalian dalam diri, kecerdasan kepribadian, serta kemampuan yang dibutuhkan dalam diri, masyarakat, negar, dan bangsa. UU SISDIKNAS (2003) Untuk melancarkan suatu kegiatan pendidikan, maka bisa dilaksanakan dalam kegiatan suatu pembelajaran. Dimana dalam pembelajaran diperlukan dan disiapkan seorang guru profesional yang dapat melaksanakan, merencanakan, dan melakukan pemantauan dan evaluasi, juga memberikan sebuah jaminan mutu dan bertanggungjawab dalam pembelajaran. Proses kegiatan pembelajaran yang berkualitas tentunya ada faktor pendukung seperti media pembelajaran.

Media pembelajaran merupakan suatu sarana untuk mempermudah dalam tercapainya tujuan ilmu pengetahuan dan bisa mempermudah pencapaian dari hasil dan pembelajaran yang lebih efektif. UU SISDIKNAS (2003) Sehingga media merupakan bagian komponen utama yang harus ada didalam kegiatan sebuah pembelajaran. Dengan terciptanya media proses pembelajaran lebih berarti juga lebih mudah di mengerti oleh siswa. Ular Tangga ialah bentuk permainan yang terbuat dari papan, bagi anak dipermaikan dalam dua anak atau bahkan lebih. Papan didalam sebuah permainan ini terbagi sebuah kotak-kotak yang berbtentuk kecil dan didalam sejumlah kotak terdapat beberapa tangga dan ular yang digambar dengan fungsi menghubungkan dengan kotak yang lainnya. Media pembelajaran permainan sebuah ular tangga merupakan media yang digunakan didalam suatu pembelajaran dikembangkan dengan berdasarkan sebuah permainan ular tangga yang bersifat tradisional disesuaikan dengan karakter siswa bertujuan untuk tercapainya tujuan dari sebuah kegiatan pembelajaran sebagai seubuah pengiring informasibagi siswa. Rifki (2019)

Penjelasan diatas sama atau sejalan dengan penelitian Mukaroma dan Nailussunah. Penelitian Mukaorma yang berjudul "Pengembangan media pembelajaran permainan ular tangga untuk meningkatkanmotivasi belajar siswa dan hasil belajar IPS di sekolah dasar". Richatul (2018) Sedangkan, penelitian Nailussunah yang berjudul "Efektifitas pembelajaran matematika menggunakan media pembelajaran ular tangga pada materi perbandingan di kelas VII MTs Nurul Huda Kalanganyar Sedati Sidoarjo". Ayyuniswin (2010) Berdasarkan peneliti-peneliti tersebut bisa diambil kesimpulan bahwasannya media pembelajaran ular tangga memiliki kelayakan untuk dikembangkan.

Kurikulum yang dipakai pada saat ini merupakan kurikulum 2013 yang dipakai sebagai tuntutan di era globalisasi. Kurikulum ini menekankan pada pendidikan karakter atau membentuk karaktersiswa yang baik dengan menekankan pada upaya berfikir kritis atau yang disebut dengan HOTS (Higher Order Thinking Skill). Menurut Thomas dan Thorne HOTS adalah cara berfikir yang lebih tinggi dari pada menghafal, mengemukakan, atau menerapkan peraturan, prosedur, dan rumus. HOTS mewajibkan seseoreang melaksanakan suatu dengan berdasar kenyataan. Membuat keterhubungan antar fakta, mengategorikan, memanipulasinya, dengan menempatkannya didalam konteks yang belum pernah dilakukan, dan bisa menerapkannya dalam mendapatkan solusi yang baru didalam suatu permasalahan. Nugroho (2018) Sehingga HOTS ini sangat baik digunakan untuk melatis siswa berlatih berfikir tingkat tinggi yaitu $\mathrm{C} 4$, C5, dan C6. Berdasarkan permasalahan tersebut peneliti berupaya memberikan soslusi kepada guru tersebut dengan memakai media pembelajaran permaianan ular tangga berbasis soal hots. Karena dengan soal hots akan melatih siswa untuk berfikir tingkat tinggi tidak hanya menghafal melainkan dapat menganalisis, mengevaluasi, dan mencipta. Soal-soal HOTS dapat digunakan guru untuk mengukur hasil belajar siswa.

Berdasarkan uraian tersebut, saat ini telah tersedia media pembelajaran dalam bentuk permainan untuk latihan yang dikembangkan oleh Faisal (2020). Media ini telah di uji validitas dan praktikalitasnya, namun media ini belum di uji efektivitasnya terhadap hasil belajar siswa. Oleh karena itu, penulis tertarik melakukan penelitian dengan judul "Efektivitas Penggunaan Media Permainan Ular Tangga Pada Materi Kerajaan Islam, Hindu dan Budha Berbasis Soal HOTS Untuk Meningkatkan Hasil Belajar Siswa di SDN Ngaringan 03 Blitar".

\section{METODE}

Jenis penelitian yang digunakan dalam penelitian adalah eksperimen semu (Quasi Experimental Design). Eksperimen 
ini mempunyai kelompok kontrol tetapi tidak dapat berfungsi sepenuhnya untuk mengontrol variabel-variabel luar yang mempengaruhi pelaksanaan eksperimen. Sugiyono (2013) Rancangan yang digunakan adalah Non-equivalent Control Group Design. Bentuk rancangan penelitiannya dapat dilihat pada Tabel 1:

TABLE 1 | Rancangan Penelitian Non-Eqivalent Control Group Design

\begin{tabular}{llll}
\hline Kelas & Pretest & Perlakuan & Posttest \\
\hline Eksperimen & O1 & $\mathrm{X}$ & O3 \\
Kontrol & $\mathrm{O} 2$ & - & O4 \\
\hline
\end{tabular}

\section{Keterangan:}

O1 : tes awal untuk kelas eksperimen

$\mathrm{O} 2$ : tes awal untuk kelas kontrol

O3 : tes akhir untuk kelas eksperimen

$\mathrm{O} 4$ : tes akhir untuk kelas kontrol

$\mathrm{X}$ : pembelajaran dengan menggunakan media ular tangga

Penelitian ini dilakukan pada bulan Mei-Juli di SDN Ngaringan 03 Blitar pada tahun pelajaran 2019/2020. Populasi dalam penelitian ini adalah seluruh siswa kelas IV di SDN Ngaringan Blitar. Sampel diambil dalam penelitian ini menggunakan teknik purposive sampling. Teknik purposive sampling merupakan teknik pengambilan sampel dengan pertimbangan tertentu. Sugiyono (2013) Penelitian mengambil sampel berdasarkan kelas yang diajarkan oleh guru yang sama dan berdasarkan pertimbangan bahwa dua kelas tersebut memiliki kemampuan yang seimbang. Langkah-langkah dalam pengambilan sampel berdasarkan purposive sampling adalah dengan menentukan kelas sampel dengan teknik purposive sampling sehingga didapatkan dua kelas sampel untuk dijadikan kelas kontrol dan kelas eksperimen. Kelas eksperimen pada penelitian ini kelas 4A dan kelas kontrol adalah 4B. Sebelumnya kelas sampel diambil berdasarkan pertimbangan nilai ujian materi kerajaan hindu, budha, islam dari kedua kelas dan dilakukan uji normalitas dan homogenitas masing-masing kelas sampel. Pada uji pada sampel tersebut didapatkan kedua kelas sampel yang normal dan homogen. Variabel pada penelitian ini yaitu:

Variabel independen/bebas, yaitu variabel yang mempengaruhi atau yang menjadi sebab perubahan/timbulnya variabel terikat. Pada penelitian ini yang menjadi variabel bebas adalah pembelajaran dibantu media ular tangga pada kelas eksperimen dan pembelajaran seperti biasa pada kelas kontrol. Variabel dependen/terikat, yaitu variabel yang dipengaruhi atau yang menjadi akibat, karena adanya variabel bebas. Pada penelitian ini yang menjadi variabel terikat adalah hasil belajar siswa yang diperoleh dari hasil pretest dan posttest pada kelas eksperimen dan kontrol. Variabel kontrol, yaitu variabel yang dikendalikan atau dibuat konstan sehingga pengaruh variabel bebas terhadap variabel terikat tidak dipengaruhi oleh faktor luar yang tidak teliti. Pada penelitian ini yang menjadi variabel kontrol semuanya haruslah dibuat sama diantaranya: 1) kemampuan awal siswa adalah sama, 2) materi, buku sumber dan alokasi waktu yang digunakan adalah sama, 3) guru yang mengajar dan cara mengajar yang digunakan adalah sama dan, 4) jenis dan jumlah soal yang diujikan adalah sama.
Data penelitian adalah informasi berupa fakta yang diperoleh dari penelitian agar dapat diolah guna pengambilan keputusan. Data yang digunakan dalam penelitian ini adalah data primer yang diperoleh dari hasil belajar siswa di kelas sampel melalui tes awal (pretest) dan tes akhir (posttest). Sumber data dalam penelitian ini adalah siswa pada kelas sampel. Teknik analisa yang digunakan dalam penelitian adalah uji N-Gain, uji normalitas, uji homogenitas dan uji hipotesis. Uji N-Gain digunakan untuk mengetahui peningkatan hasil belajar kognitif siswa sebelum dan sesudah pembelajaran pada kelas eksperimen dan kelas kontrol. Uji normalitas digunakan untuk melihat apakah sampel berasal dari populasi yang terdistribusi normal atau tidak.Uji homogenitas bertujuan untuk melihat apakah data pada kedua sampel mempunyai varians yang homogen atau tidak. Uji hipotesis bertujuan untuk menentukan apakah hipotesis penelitian dapat diterima atau ditolak.

\section{HASIL DAN PEMBAHASAN}

\section{Hasil}

Berdasarkan penelitian yang telah dilakukan di SDN Ngaringan 03 Blitar diperoleh data hasil belajar siswa pada kompetensi kognitif. Data penelitian ini diperoleh melalui penilaian hasil belajar siswa pada tes awal (pretest) dan tes akhir (posttest). Tes yang dilakukan berupa soal pilihan ganda sebanyak 25 butir soal dengan 5 pilihan jawaban yang diambil dari 40 soal yang telah diujicobakan. Data penelitian ini dimulai dengan pemberian tes awal (pretest) kepada kelas sampel sebelum memulai proses pembelajaran. Tes awal diberikan bertujuan untuk mengetahui kemampuan awal siswa. Secara ringkas ratarata pretest siswa pada kedua kelas sampel dapat dilihat pada Tabel 2.

\begin{tabular}{ccc}
\multicolumn{2}{l}{ TABLE 2 | Rata-rata Prestest Kelas Sampel } \\
\hline \multirow{2}{*}{ Kelas } & $\mathrm{N}$ & Rata-rata pretest \\
\hline Eksperimen & 25 & 65,84 \\
Kontrol & 25 & 62,4 \\
\hline
\end{tabular}

Tes yang kedua adalah tes akhir (posttest) yang diberikan setelah pertemuan berakhir pada proses pembelajaran yang bertujuan untuk mengetahui hasil belajar siswa setelah diberi perlakuan. Secara ringkas hasil posttest siswa pada kelas eksperimen dan kelas kontrol dapat dilihat pada Tabel 3.

\begin{tabular}{ccc}
\multicolumn{2}{c}{ TABLE 3 | Rata-rata Posttest Kelas Sampel } \\
\hline Kelas & $\mathrm{N}$ & Rata-rata posttest \\
\hline \multirow{2}{*}{ Eksperimen } & 25 & 92,12 \\
Kontrol & 25 & 73,96 \\
\hline
\end{tabular}

Data yang diperoleh dari pretest dan posttest selanjutnya diolah dan dianalisis untuk penarikan kesimpulan. Penarikan kesimpulan menggunakan uji hipotesis atau uji kesamaan dua rata-rata secara statistik. Sebelum melakukan uji hipotesis, terlebih dahulu dilakukan analisis data dengan uji N-Gain dan selanjutnya dilakukan uji normalitas dan homogenitas. Uji NGain digunakan untuk mengetahui peningkatan pemahaman dan penguasaan konsep siswa yang dapat dilihat dari hasil belajar kognitif sebelum dan sesudah pembelajaran. Hasil 
rata-rata $\mathrm{N}-$ Gain pada dua kelas sampel secara ringkas dapat dilihat pada Tabel 4.

\begin{tabular}{ccc}
\multicolumn{2}{c}{ TABLE 4 | Rata-rata Posttest Kelas Sampel } & \\
\hline Kelas & Rata-rata N-Gain & Kriteria \\
\hline Eksperimen & 0,762289 & Tinggi \\
Kontrol & 0,294189 & Rendah \\
\hline
\end{tabular}

Uji normalitas digunakan untuk mengetahui apakah data terdistribusi normal atau tidak. Uji normalitas yang dilakukan dalam penelitian ini menggunakan uji Lilliefors. Hasil uji normalitas dari hasil penelitian dapat dilihat pada Tabel 5.

TABEL 5 | Tests of Normality

\begin{tabular}{cccccccc}
\hline & \multicolumn{3}{c}{ Kolmogorov-Smirnov $^{\text {a }}$} & \multicolumn{4}{c}{ Shapiro-Wilk } \\
\hline \multicolumn{2}{c}{ kelas } & Statistic & $\mathrm{df}$ & Sig. & Statistic & $\mathrm{df}$ & Sig. \\
\hline \multirow{2}{*}{ gain } & 1 & .161 & 25 & .094 & .938 & 25 & .135 \\
& 2 & .144 & 25 & .194 & .957 & 25 & .362 \\
\hline
\end{tabular}

a. Lilliefors Significance Correction

Selanjutnya dilakukan uji homogenitas digunakan untuk melihat apakah data pada kedua sampel mempunyai varians yang homogen atau tidak. Uji homogenitas dilakukan dengan mennggunakan Uji F. Tabel 6 menunjukkan hasil pengolahan data untuk uji homogenitas.

\begin{tabular}{|c|c|c|c|}
\hline gain & & & \\
\hline Levene Statistic & df1 & $\mathrm{df} 2$ & Sig. \\
\hline .092 & 1 & 48 & .763 \\
\hline
\end{tabular}

Uji yang terakhir adalah uji hipotesis digunakan untuk menentukan apakah hipotesis penelitian dapat diterima atau tidak. Berdasarkan uji normalitas dan uji homogenitas dari data selisih nilai tes awal dan tes akhir, terlihat bahwa hasil belajar kedua kelas sampel terdistribusi normal dan memiliki varians yang homogen. Untuk itu, dilakukan uji kesamaan dua rata-rata dengan menggunakan uji-t, seperti terlihat pada Tabel 7.

TABEL 7 | Group Statistics

\begin{tabular}{|c|c|c|c|c|c|}
\hline & kelas & $\mathrm{N}$ & Mean & Std. Deviation & Std. Error Mean \\
\hline \multirow{2}{*}{ gain } & 1 & 25 & .7622 & .12141 & .02428 \\
\hline & 2 & 25 & .3012 & .12441 & .02488 \\
\hline
\end{tabular}

\begin{tabular}{|c|c|c|c|c|c|c|c|c|c|c|}
\hline & & \multicolumn{9}{|c|}{$\begin{array}{l}\text { Levene's Test } \\
\text { for Equality of } \\
\text { Variances t-test for Equality of Means }\end{array}$} \\
\hline & & \multirow[b]{3}{*}{$\mathrm{F}$} & \multirow[b]{3}{*}{ Sig. } & \multirow[b]{3}{*}{$t$} & \multirow[b]{3}{*}{ df } & \multirow[b]{3}{*}{ Sig. (2-tailed) } & \multirow{3}{*}{$\begin{array}{l}\text { Mean } \\
\text { Difference }\end{array}$} & \multirow{3}{*}{$\begin{array}{l}\text { Std. Error } \\
\text { Difference }\end{array}$} & \multirow{2}{*}{\multicolumn{2}{|c|}{$\begin{array}{l}95 \% \text { Confidence } \\
\text { Interval of the } \\
\text { or Difference }\end{array}$}} \\
\hline & & & & & & & & & & \\
\hline & & & & & & & & & e Lower & Upper \\
\hline \multirow[b]{2}{*}{ gain } & $\begin{array}{l}\text { Equal } \\
\text { variances } \\
\text { assumed }\end{array}$ & .092 & .763 & 13.261 & 48 & .000 & .46105 & .03477 & .39115 & .53095 \\
\hline & $\begin{array}{l}\text { Equal } \\
\text { variances } \\
\text { not } \\
\text { assumed }\end{array}$ & & & 13.261 & 47.971 & .000 & .46105 & .03477 & .39114 & .53095 \\
\hline
\end{tabular}

Berdasarkan tabel diatas didapatkan mean kelas eksperimen adalah 0.7622. Dan mean kelas kontrol 0.3012. Kriteria pengujian adalah terima $\mathrm{H0}$ jika thitung < ttabel. Hasil perhitungan menunjukkan bahwa harga t berada di luar daerah penerimaan $\mathrm{H} 0$, sehingga $\mathrm{H} 0$ ditolak pada taraf nyata 0,05 dan $\mathrm{H} 1$ diterima. Ini menunjukkan bahwa hasil belajar kelas eksperimen lebih tinggi dari kelas kontrol.

\section{Pembahasan}

Penelitian ini bertujuan untuk mengungkapkan tingkat efektivitas penggunaan media ular tangga pada materi kerajaan Islam, Hindu dan Budha berbasis soal HOTS untuk meningkatkan hasil belajar siswa di SDN Ngaringan 03 Blitar. Permainan ular tangga kerajaan Islam, Hindu, dan Budha adalah media permainan untuk latihan dalam pemantapan konsep siswa terhadap materi yang telah dipelajari. Dalam penelitian ini ada dua kelas sampel yaitu kelas eksperimen dan kelas kontrol yang menjadi objek penelitian dan nantinya akan dilihat peningkatan hasil belajar antara kedua sampel tersebut.

Sebelum dilakukan proses pembelajran pada materi kerajaan Islam, Hindu dan Budha, masing-masing kelas sampel diberi tes awal (pretest) yang bertujuan untuk menguji pengetahuan atau kemampuan awal siswa mengenai materi yang akan dipelajari. Kemudian didapatkan nilai rata-rata pretest kelas eksperimen adalah 65,84 sedangkan pada kelas kontrol adalah 62,4. Nilai rata-rata pretest kedua kelas sampel memiliki perbedaan yang tidak terlalu besar, hal ini menandakan bahwa kedua kelas sampel memiliki kemampuan awal yang relatif sama. Pada proses pembelajaran pada masing-masing sampel diberi perlakuan yang sama berupa materi yang diajarkan, buku sumber, alokasi waktu dan cara mengajar yang sama. Materi kerajaan Islam, Hindu, dan Budha ini memuat banyak konsep yang harus dipahami oleh siswa. Oleh karena itu dalam proses pembelajaran siswa dituntut untuk banyak membaca, berdiskusi, serta aktif dalam mengerjakan latihan guna meningkatkan pemahaman dan pemantapan konsep siswa terhadap materi yang dipelajari. Hal ini juga didukung oleh pendapat Smaldino (2011: 33), bahwa untuk meningkatkan penguasaan siswa mengenai materi konsep, prinsip, atau prosedur yang telah dipelajari maka diperlukan latihan. Perlakuan yang berbeda pada masingmasing kelas sampel hanya pada saat pemberian latihan, dimana kelas eksperimen menggunakan media permainan ular tangga kerajaan sedangkan pada kelas kontrol menggunakan buku cetak tematik yang digunakan sekolah seperti biasa.

Pada kelas eksperimen pemberian latihan menggunakan media permainan ular tangga kerajaan dilakukan pada pertemuan keempat. Waktu yang digunakan dalam permainan ini selama kurang lebih 45 menit atau 1 jam pelajaran. Latihan sambil bermain ular tangga yang dilakukan selama 45 menit dapat berjalan cukup baik. Pada kelas eksperimen ini semua siswa termotivasi dan ikut berpartisipasi aktif dalam melakukan latihan sambil bermain karena bersifat menyenangkan dan menumbuhkan jiwa kompetitif dan dapat dijadikan upaya pemantapan konsep siswa terhadap materi yang telah dipelajarinya. Pada kelas kontrol pemberian latihan menggunakan buku cetak tematik yang ada disekolah dan latihan juga dilakukan pada pertemuan keempat dan waktu yang sama yaitu 45 menit atau 1 jam pelajaran. Ketika pengerjaan soal-soal latihan siswa memiliki motivasi yang rendah dan kurang aktif untuk mengerjakan soal, mereka lebih cenderung banyak berbicara dengan siswa sebelahnya dan ada juga yang melihat hasil jawaban siswa lainnya tanpa memahami soal-soal tersebut. Setelah pemberian latihan yang 
dilakukan baik itu kelas eksperimen dan kelas kontrol diberi tes akhir (posttest). Tes akhir yang diberikan pada masingmasing kelas sampel memiliki jenis soal dan jumlah yang sama.

Tes akhir (posttest) dilakukan dengan tujuan untuk mengetahui hasil belajar yang dicapai siswa setelah diberi perlakuan. Nilai posttest pada kelas eksperimen dan kelas kontrol dapat dilihat pada tabel 3 dimana nilai rata-rata posttest pada kelas eksperimen adalah 92,12 sedangkan pada kelas kontrol adalah 73,96. Dari nilai rata-rata posttest antara kedua kelas sampel tersebut dapat dilihat bahwa nilai posttest kelas eksperimen lebih tinggi dibandingkan dengan kelas kontrol. Nilai rata-rata posttest kedua kelas sampel memiliki perbedaan yang signifikan, hal ini menandakan bahwa adanya pengaruh pemberian perlakuan yang berbeda pada masing-masing kelas sampel terhadap hasil belajar siswa.

Hasil data pretest dan posttest kemudian dihitung ratarata $\mathrm{N}$-Gain masing-masing kelas sampel dapat dilihat pada tabel 4. Kelas eksperimen memiliki rata-rata N-Gain sebesar 0,762289 dengan kategori tinggi dibandingkan dengan kelas kontrol memiliki rata-rata $\mathrm{N}$-Gain sebesar 0,294189 dengan kategori rendah. Hal ini menunjukkan bahwa terjadi peningkatan hasil belajar kognitif siswa yang lebih baik oleh kelas eksperimen yang menggunakan media permainan ular tangga kerajaan dibandingkan kelas kontrol.

Penggunaan media permainan ular tangga juga dapat membuat pengalaman menarik dan menyenangkan bagi siswa dalam mengerjakan latihan untuk pemantapan konsep siswa. Pada saat menggunakan media permainan ular tangga kerajaan siswa menjadi tertarik mengerjakan latihan tanpa komentar dan menyukai adanya permainan. Hal ini didukung oleh pendapat Hamdani (2011: 93) bahwa media permainan dapat memberikan pengalaman yang menarik bagi siswa dalam memahami suatu konsep maupun penguatan konsep yang telah dipahami serta dapat menjadikan lingkungan belajar lebih menyenangkan. Selain itu juga terlihat pada saat siswa mengerjakan latihan sambil bermain sehingga tercipta suasana yang menyenangkan. Hal ini sesuai dengan ungkapan Nugrahani (2007: 36) bahwa ketika siswa belajar dalam kondisi menyenangkan, maka siswa bisa menyerap dan mengingat lebih banyak materi yang disampaikan. Jadi dapat disimpulkan bahwa media permainan ular tangga sangat efektif untuk meningkatkan pemantapan konsep siswa terhadap pelajaran.

Media permainan ular tangga juga membuat siswa mengingatkan kembali pelajaran atau materi yang telah diajarkan. Pada permainan ini siswa dapat berulangkali menjawab soal pertanyaan sampai menuju finish. Hal ini terlihat saat koordinator membacakan soal untuk pemain A dan pemain lainnya ( $B, C$ dan $D$ ) secara tidak langsung ikut mendengarkan dan memperkirakan jawabannya. Jika soal selesai dibacakan dan dijawab oleh pemain, maka koordinator membacakan jawaban yang benar. Sehingga setiap pemain dan koordinator dalam melaksanakn latihan dengan permainan ular tangga kerajaan ikut mengetahui kebenaran dari pertanyaan yang ada. Pengulangan dalam latihan menggunakan permainan ini akan memperkuat konsep-konsep yang telah dipelajari siswa. Hal ini sesuai dengan pendapat Sanjaya (2013: 97) yang menyatakan bahwa pengulangan, latihan dan penguatan merupakan suatu usaha dalam rangka memperkuat pengusaan terhadap pelajaran. Jadi dapat disimpulkan bahwa permainan ular tangga ini juga efektif untuk memperkuat penguasaan terhadap pelajaran sehingga hasil belajar akan meningkat.

Berdasarkan pembahasan diatas, dapat disimpulkan hasil belajar pada kompetensi kogintif siswa yang menggunakan media permainan ular tangga kerajaan lebih tinggi secara signifikan dibandingkan dengan hasil belajar siswa yang tidak menggunakan media permainan ular tangga atau hanya menggunakan latihan mengunakan buku cetak tematik pada proses pembelajaran. Hal ini membuktikan bahwa pengunaan media permainan ular tangga pada materi koloid efektif meningkatkan hasil belajar siswa.

Selama penelitian berlangsung terdapat kendala yang ditemui dalam pelaksanaan pembelajaran yaitu sebelum permainan dimulai peneliti menyampaikan tatacara aturan permainan dan setelah dibacakan tidak ada yang bertanya lagi. Beberapa saat kemudian ketika permainan sudah dimulai masih ada beberapa koordinator yang bertanya-tanya tentang aturan permainan. Hal ini akan memakan waktu untuk kelompok tersebut untuk bermain. Selain itu, rata-rata waktu latihan sambil bermain ini juga memakan waktu yang lama pada beberapa kelompok. Karena pada saat setelah 45 menit waktu untuk bermain hanya 3 kelompok yang telah menyelesaikan permainan karena telah sampai finish dan 3 kelompok lainnya belum sampai kefinish. Untuk menyelesaikan semua kelompok untuk sampai ke finish nantinya akan memakan waktu yang lama sedangkan alokasi waktu pelajaran terbatas. Sehingga solusi untuk penelitian selanjutnya pada aturan permainan dapat dibuatkan secara ringkas kembali agar penyampaian aturan permainan tidak memakan waktu yang lama. Kemudian untuk beberapa kelompok yang belum sampai ke finish sedangkan waktu yang disediakan terbatas hendaknya banyak soal pada permainan tersebut dikurangi daripada sebelumnya. Soal yang dikurangi secara kuantitas tetapi soal-soal tetap mewakili indikator pencapaian kompetisi pada pelajaran tanpa mengurangi kualitas soalnya.

\section{KESIMPULAN}

Berdasarkan hasil penelitian, pengolahan data dan analisi data yang telah dilakukan tentang efektivitas penggunaan permainan ular tangga kerajaan islam,Hindu, Budha terhadap hasil belajar siswa di SDN Ngaringan 03 Bltar dapat ditarik kesimpulan bahwa penggunaan permainan ular tangga kimia efektif meningkatkan hasil belajar siswa kelas 4 SDN Ngaringan 03 Bltar. Hal ini dibuktikan dengan nilai N-Gain bahwa peningkatan hasil belajar kognitif siswa kelas eksperimen memiliki kategori tinggi sedangkan kelas kontrol memiliki kategori rendah. 


\section{REFRENCES}

Afandi rifki. 2014. Pengembangan media pembelajaranpermainan ular tangga untuk meningkatkanmotivasi belajar siswa dan hasil belajar ipsdi sekolah dasar. (tersedia. www.researchgate.net) diakses 11 desember 2019.

Ahmad Patoni, dkk, 2004. Dinamika Pendidikan Anak. Jakarta : PT. Bina Ilmu.

Arief S.Sadiman, dkk. 2003. Media Pembelajaran. Jakarta : PT Raja Grafindo Persada.

Asep Jihad dan Abdul Haris. 2013. Evaluasi Pembelajaran. Yogyakarta : Multi Presindo.

Asnawir dan Basyirudin Usman. 2002. Media Pembelajaran. Jakarta : Ciputat Press.

Azhar Arsyad. 2006. Media Pembelajaran. Jakarta : PT Rajagrafindo.

Dwi Diana Putri. 2018. Pengembangan Media Evaluasi Pembelajaran Berbentuk Permaian Ular Tangga Untuk Meningkatkan Motivasi Belajar Siswa Pada Siswa Kelas IV Sekolah Dasar Negeri Kebonduren 01 Kebupaten Blitar. skripsi, PGMI. UIN Malang.

Heni endayani. 2017. pengembangan materi ajar ilmu pengetahuan sosial, jurnal pendidikan ilmu pengetahuan sosial FITK UIN SU Medan, vol 1, no 1.

HM. Musfiqon. 2012. Pengembangan Media dan Sumber Pembelajaran. Jakarta : Prestasi Pustakarya.

Lely Gusliana Novia. 2013. Pengembangan Media Pembelajaran Permaian Ular Tangga Segitiga Dan Jajargenjang Untuk Meningkatkan Hasil Belajar Matematika Siswa Kelas IV Di MI Jamiyatut Tholibin Kabupaten Blitar, skripsi, PGMI. UIN Malang.

Mukaromah Richatul. 2018. bimbingan konseling pada ibu yang memiliki anak berkebutuhan khusus pada usia sekolah dasar melalui permainan ular tangga di Desa Kedung Kendo. skripsi UIN Sunan Ampel Surabaya.

Nailussunah Ayyuniswin. 2010. Efektifitas pembelajaran matematika menggunakan media pembelajaran ular tangga pada materi perbandingan di kelas VII MTs Nurul Huda Kalanganyar Sedati Sidoarjo. skripsi UIN Sunan Ampel Surabaya.
Nana Syaodih Sukmadinatta. 2007. Metode Penelitian Pendidikan, Bandung : PT. Remaja Rosdakarya.

R. Arifin Nugroho. 2018. HOTS. Jakarta : Gramedia Widiasarana Indonesia.

Ramandhita Dwi Pranata. 2016. Pengembangan Ular Tangga Edukatif Pada Materi Limit Kelas X SMK, skripsi, pendidikan matematika. Universitas Negeri Malang.

Selly Effa Weranti. 2017. pengaruh media diporama tiga dimensi untuk meningkatkan hasil belajar kognitif materi mengenal penggunaan uang mapel IPS kelas III SDN Balung Bowo, skripsi, PGSD. Universitas Muhammadiyah Sidoarjo.

Sugiyono. 2013. Metode penelitian kuantitatif,kualitatif,dan R\&d. Bandung : CV. Alfabeta.

Undang-undang Sistem Pendidikan Nasional No. 20 Tahun 2003. Bandung: Fokusmedia, 2010.

Yoga Krestama, Penggunaan Media Diorama untuk Meningkatkan Hasil Belajar IPS Materi Arah dan Letak Rumah pada Siswa Kelas 1A SD Muhammadiyah 09 Malang, (skripsi, PGSD. Universitas Muhammadiyah. 2013).

Conflict of Interest Statement: The authors declare that the research was conducted in the absence of any commercial or financial relationships that could be construed as a potential conflict of interest.

Copyright (C) 2020 Lisaniyah and Salamah. This is an open-access article distributed under the terms of the Creative Commons Attribution License (CC BY). The use, distribution or reproduction in other forums is permitted, provided the origi- nal author(s) and the copyright owner(s) are credited and that the original publication in this journal is cited, in accordance with accepted academic practice. No use, distribution or reproduction is permitted which does not comply with these terms 